\title{
Appraising Justice as Larger Loyalty
}

\author{
David Rondel
}

Department of Philosophy, University of Nevada, Reno, Nevada 89509, USA drondel@unr.edu

\begin{abstract}
I examine Richard Rorty's “justice as larger loyalty" proposal. He urges that we think of justice as a more capacious loyalty, rather than something altogether distinct from loyalty. While Rorty is right to reject the Kantian idea of a strict bifurcation between justice and loyalty, the former corresponding to reason the latter corresponding to sentiment, my argument is that it is nevertheless a mistake to follow Rorty in conceiving of justice as he recommends we should. This is not an endorsement of the rationalistic Kantian view Rorty rejects. Contrary to what Rorty sometimes implies, it is possible to be skeptical about the "justice as larger loyalty" thesis without thereby committing oneself to Kant's view. There are compelling Rortyan reasons for rejecting the "justice as larger loyalty" proposal, which are not merely compatible with Rorty's broader moral and political thinking, but paradoxically very much in its spirit.
\end{abstract}

\section{Keywords}

Richard Rorty - justice - loyalty - Immanuel Kant - liberalism - moral philosophy political philosophy

"[T]he extent of your cooperation in social projects is a proper object of public concern, but your private projects are your own business, as long as they can be carried out within the framework of just laws and institutions."

— RICHARD RORTY, "Intellectual Autobiography" (2010b) 
Richard Rorty did not have a great deal to say about justice, both in the uniquely philosophical and more ordinary senses of that term. On the one hand, Rorty would have certainly denied that there is some pure and unchanging ideaJustice with a capital "J" if you like-whose essential nature it is the business of philosophy to uncover. Only those in the grip of what Rorty (1979) famously labeled Philosophy with a capital "P", those who, like Plato and Kant, attempt to "derive solutions to moral dilemmas from the analysis of moral concepts" (Rorty 2001, 228) could possibly think such a thing. On the other hand, Rorty also had relatively little to say about justice in the more ordinary, everyday sense - the sense of justice in whose name men and women from all walks of life organize, deliberate, mobilize, and struggle. ${ }^{1}$ As Rorty would frequently admit, he had no interesting suggestions about the ways in which concrete injustices of this or that sort might be remedied or overcome; no novel ideas about how to craft superior political institutions or alleviate social misery. "I don't think anybody has any bright political ideas lately and I don't have any myself," Rorty wrote in a letter to his former student, Barry Allen.

In the absence of such ideas all I have to say is 'Be socially concerned: i.e., bear in mind that us leisured intellectuals get our leisure at the expense of people who are suffering.' But I [know] this doesn't sound very impressive unless I have some constructive suggestions about how to alleviate the suffering, and I don't...I have no political initiatives to offer. (cf. Allen 2008, 198)

It is a common thought that, insofar as Rorty's work is useful for thinking about justice, such usefulness is largely metaphilosophical. It consists in a series of

1 This is not to say that Rorty was without political stances. As is well known, he was a nostalgic champion of the redistributive policies of the New Deal, the struggles and victories of the labor movement, civil rights groups, feminist suffragettes, along with a diverse group of figures like Irving Howe, Eugene Debs, Herbert Croly, Norman Thomas, Martin Luther King Jr., Hubert Humphrey, and FDR. On Rorty's view, such figures belonged to what he called the "reformist left" a term that covers all those Americans who, "between 1900 and 1964 struggled within the framework of constitutional democracy to protect the weak from the strong." The "reformist left" is sharply distinguished from the so-called "New Left," a term that Rorty used to cover those people, most of whom were students, who decided sometime around 1964, "that is was no longer possible to work for social justice within the system." (Rorty 1998b, 43) As Rorty tells the story (cf. Rorty 1998b and 2002), the reformist left was concerned above all with economic justice and enjoyed strong connections with organized labor. The New Left by contrast began to worry less about economic inequality, and more about "culture" and "stigma". 
reminders about being on guard against the dangers of lofty philosophical ambitions like Platonic objectivity, Cartesian certainty, and Kantian transcendence, and in avoiding the traps set by Rorty's traditional cast of villains: foundationalists, essentialists, realists, Platonists, Kantians, and "metaphysical prigs" who believe in a correspondence theory of truth and a way the world fundamentally, enduringly is.

One small exception to Rorty's silence about the topic of justice can be found in a later essay: "Justice as Larger Loyalty." In that paper Rorty suggests that we think of "justice" as the name for "loyalty to a certain very large group, the name for our largest current loyalty, rather than the name of something distinct from loyalty...Could we replace the notion of 'justice," Rorty asks, "with that of loyalty to that group-for example, one's fellow citizens, or the human species, or all living things? Would anything be lost by this replacement?" (Rorty 2001, 225)

In what follows I examine the "justice as larger loyalty" suggestion and try to place it sympathetically within the larger context of Rorty's moral and political thought. ${ }^{2}$ While Rorty is right, I argue, to reject the Kantian idea of a strict bifurcation between justice and loyalty, the former corresponding to reason the latter corresponding to sentiment, my argument is that it is nevertheless a mistake to follow Rorty in conceiving of justice as he recommends we should. To be clear, this is not an endorsement of the rationalistic Kantian view Rorty rejects. Contrary to what Rorty sometimes implies, it is possible to be skeptical about the "justice as larger loyalty" thesis without thereby being forced toward the Kantian view. But more centrally and interestingly, my argument is that there are compelling Rortyan reasons-reasons internal to Rorty's own liberal political theory—for rejecting the "justice as larger loyalty" proposal. My main task in what follows will be to show how the argument against that proposal is not merely compatible with Rorty's broader moral and political thinking, but paradoxically, very much in its spirit.

This is a worthwhile undertaking not simply because it sheds light on Rorty's (surprisingly rare) thinking about this age-old philosophical topic, but also

2 Although it goes unmentioned by Rorty, there are obvious affinities here with Josiah Royce insofar as Royce too put loyalty at the center of his understanding of justice and morality. Unlike Rorty, however, Royce assigns to loyalty a more foundational role in moral thinking. As Royce writes, "In loyalty... is the fulfillment of the whole moral law. You can truthfully center your entire moral world about a rational conception of loyalty. Justice, charity, industry, wisdom spirituality, are all definable in terms of enlightened loyalty." (Royce 2005, 860) Rather surprisingly, Rorty confesses to having "never gotten much out of [Royce's book] The Philosophy of Loyalty...I do not disagree with what he said in that book," he continues, "but I find it neither original nor inspiring." (Rorty 2010a, 136). 
because it suggests possibilities for contemporary pragmatists to think more perspicaciously about the theory of justice. If Robert Talisse is right to say that, "The current neglect of justice among pragmatist political philosophers cannot continue," and that "We [pragmatists] need a theory of justice" (Talisse 2014,177 ) then I propose that appraising Rorty's "justice as larger loyalty" idea can be understood as some preliminary work toward that larger end.

\section{Expanding the Range of Our Present "We"}

Rorty's justice as larger loyalty thesis is consonant both with a Darwinian understanding of human beings and a thoroughly secular way of thinking of morality. In fact, when Rorty identifies the most important change produced by secularism as "the shift from thinking of morality as a matter of unconditional prohibitions to seeing it as an attempt to work out compromises between competing human needs" (Rorty 2007, 147 n1), it is natural to interpret the "justice as larger loyalty" thesis as yet more Rortyan support for this shift. Just as there is no point at which we cease merely "coping" with the world and begin "representing" it, so too is there no point in our moral dealings with others at which we graduate from mere loyalty and sentiment to something else called "justice". What we call "justice," Rorty is saying, can be thought of as simply a more capacious sense of loyalty. Just as "[t]he story of how we got from Neanderthal grunts and nudges to German philosophical treatises," Rorty argues, "is no more discontinuous than the story of how we got from the amoebae to the anthropoids" (Rorty 1999, 75) so too is there no discontinuity in the story of how we got from tribal provincialism to global cosmopolitanism, from loyalties of clan or race or religion to the United Nations Declaration of Human Rights. ${ }^{3}$ It is true, Rorty says, that "When groups get larger, law has to replace custom, and abstract principles have to replace phronessis" (Rorty 2001, 227), but these are differences of degree and complexity rather than differences of kind. There is no decisive moment in our expanding encounters with othersfrom one's family to one's village to one's nation and beyond - at which loyalty gives way to something else.

3 A beautiful literary rendition of the phenomenon of such expanding encounters is found in James Joyce's Portrait of the Artist as a Young Man, at the point when Daedalus "opens the flyleaf of his geography textbook and reads what he wrote there: Stephen Daedalus/Class of Elements/Clongowes Wood College/Sallins/County Kildare/Ireland/Europe/The World/ The Universe." (Joyce 2011, 10). 
Rorty's greatest philosophical hero, John Dewey, seems to have had a similar view in mind when he distinguished between "customary" and "reflective" morality. As Dewey and Tufts put it in their 1908 Ethics "[T]he change is from 'Do those things which our kin, class, or city do' to 'Be a person with certain habits of desire and deliberation." (Dewey and Tufts 1926, 427) When groups are small and familiar, it will usually suffice to do what comes naturally and unreflectively. When groups get larger and competing interests start jostling with one another, the need to become more sophisticated, reflective, and principled arises. Like Rorty, Dewey would have wanted to view this shift as wholly continuous, as a difference only of behavioral complexity rather than one of deep philosophical kind. On the post-Darwinian view shared by Dewey and Rorty, then

there can be no sharp break between empirical and non-empirical knowledge, any more than between empirical and non-empirical practical considerations, or between fact and value. All inquiry —in ethics as well as physics, in politics as well as logic - is a matter of reweaving our webs of beliefs and desires in such a way as to give ourselves more happiness and richer and freer lives. All our judgments are experimental and fallible. Unconditionality and absolutes are not things we should strive for.

RORTY 2007, 188

All of this underpins Rorty's "ethnocentric" idea of social and moral progress. Such progress is achieved, Rorty has it, not by conformity to abstract precepts and injunctions, but by expanding one's moral ethnos, expanding the class of people to whom one feels answerable, the range of people who shall count as "one of us". On Rorty's view, the gradual expansion of our moral ethnos yields a plausible account of the moral progress we have witnessed over the course of many decades. It helps explain why, say, white males of the present generation are much less likely to hate gays and lesbians, subordinate women or oppress racial minorities than white males of our parents' generation (let alone our grandparents'). It is not because this generation is more gifted at grasping the unconditioned dictates of the moral law, or because we have somehow become more efficient tabulators of utility. It is because, unlike earlier generations, our capacities for what Rorty calls, "the imaginative ability to see strange people as fellow sufferers" (Rorty 1989, xvi) are more highly developed. It is because our moral horizons are wider and the constituents of our "we" more numerous. As Rorty put it, "The formulation of general moral principles has been less useful to the development of liberal institutions than has the gradual expansion of the imagination of those in power, their gradual willingness to use the term 
'we' to include more and more different sorts of people."4 (Rorty 1991b, 207) On this view, moral progress is more Humean than Kantian, guided more by feeling, imagination, and sentiment than by reason and principle.

These are extremely important insights and I do not want to diminish them. Yet it is curious that in the "justice as larger loyalty" essay-and only there, to the best of my knowledge-Rorty invokes the virtue of justice to make the familiarly anti-Kantian point about the moral importance of loyalty and feeling. But why depict justice as larger loyalty? Why not rather make the point in terms of "social progress as larger loyalty" or "moral improvement as larger loyalty"? Is there anything to be gained by describing the particular virtue of justice in this way? I want to argue that it is a mistake to conceive of justice along these lines, and also that this is a conclusion for which one can paradoxically find strong Rortyan support.

\section{Loyalty, Justice and Compulsion}

To see how the "justice as larger loyalty" suggestion sits uncomfortably with important strands of Rorty's political thought, it is useful to reflect on Rorty's impatience with the imbroglio of work in political theory variously branded "the politics of recognition," "the politics of difference," or "multiculturalism". "As I see it," he writes in a typical passage,

the emergence of feminism, gay liberation, various sorts of ethnic separatism, aboriginal rights, and the like, simply add further concreteness to sketches of the good old egalitarian utopia...In that society, people who wanted to think of themselves as Basque first, or black first, or women first, and citizens of their countries or of a global cooperative commonwealth second, would have little trouble doing so. For the institutions of that commonwealth would be regulated by John Stuart Mill's dictum that everybody gets to do what they like as long as it doesn't interfere with other people's doing the same.

RORTY 1999, 235

4 Rorty's so-called "ethnocentrism" has attracted an enormous critical literature. It is important to recognize, however, that the view Rorty defends is and must be a decidedly liberal one. As Barry Allen correctly remarks, "Without liberalism, [Rorty's] ethnocentrism would be awful... The liberal pragmatist is most ethnocentric precisely in scrupulously trying not to be ethnocentric in the objectionable sense" (Allen 2004, 155). As Rorty elaborates, "This culture is an ethnos which prides itself on its suspicion of ethnocentrism - on its ability to increase the freedom and openness of encounters, rather than on its possession of truth" (Rorty 1991a, 2). 
But notice that to embrace Mill's dictum in this way is effectively to deny that justice is a matter of larger loyalty. It is to say rather that justice consists in rendering to each her due (equal opportunity, respect for rights, a fair distribution of resources, and so on) while trusting that loyalty will look after itself. The hope that loyalty will look after itself forms part of the quintessentially liberal view, traceable back at least to John Locke's "Letter Concerning Toleration" and held by more or less every liberal ever since, according to which the private, inward, feeling part of our lives ought deliberately to be kept sequestered from the formal exercise of political power. Just as Locke argued that the "inward judgments" that give shape and significance to our lives cannot be promoted or demoted by compulsion, so does Rorty suggest that the idiosyncratic ordering of citizens' loyalties, their sense of themselves as Basque or black or female, is irrelevant to the just and proper functioning of a liberal polity. On this view, justice is about what we practically and concretely owe to one another, not about how our loyalties might be otherwise prioritized. There is, after all, little point telling someone that they ought not think of themselves as Basque first or black first or female first, let alone to tell them that that pattern of selfidentification is unjust.

The argument so far can be made more concrete by looking at a brilliant recent essay by Elizabeth Anderson, in which she outlines four constraints on judgments of injustice.

First, there can be no injustice without an injury to someone's interests. Second, there can be no injustice without an agent who is (or was) substantively responsible for it - someone obligated to avoid, correct, or bear the costs of the injustice or of its correction or amelioration. Third, there can be no injustice without an agent who is (or was) entitled to complain to the responsible agent, to hold that agent to account and exact compliance with the demand. Fourth, there can be no injustice where all agents continuously and successfully comply with all the demands that everyone can reasonably make of them....Where all agents conduct themselves justly - where they successfully comply with all reasonable demands - the state of affairs resulting from their conduct is just. There is no other route to defining a just state of affairs except through the concept of agents' compliance with reasonable claims people may make on each other. (Anderson 2010, 5)

I take what Anderson says here as completely uncontroversial, which is to say that I cannot conceive of any injustice, real or imagined, that failed to meet all four Andersonian conditions. After all, how could X represent an injustice if no one's interests were harmed by $\mathrm{X}$, if no one was responsible for $\mathrm{X}$, and if no one 
was legitimately entitled to complain about, and exact compliance for, X? What could it possibly mean for $\mathrm{X}$ to be unjust under these conditions? Yet if we follow Rorty in describing justice as larger loyalty, and if deficiencies of loyalty are therefore unjust (as opposed to merely unfortunate or sub-optimal in some other way) then it seems to leave space for the possibility that one may "reasonably complain" to someone else and "exact compliance" from them on account of not receiving the loyalty to which they claim they are entitled. This is an awkward, clumsy, cumbersome thought. Loyalty, like fraternity or love, is an inclination of the human heart. It is not the sort of thing for which compulsion is appropriate and rarely, if ever, the sort of thing one can be argued into having. ${ }^{5}$ In short, the prospect of demanding or coercing loyalty is no less farfetched than the prospect of forcing onto someone what John Locke called "true and saving religion." ${ }^{\prime}$

Keeping "inward judgments" safe from formal coercion is by now liberal prosaicism. It should therefore come as no surprise that a parallel theme plays a prominent role in Rorty's political thought. I am thinking here of Rorty's much maligned split between a humane "public" orientation and "private" ironic one. Despite frequent, sometimes vociferous attempts by critics to repudiate it, I think that Rorty's central argument in Contingency, Irony, and Solidarity - viz., that "there is no way bring self-creation together with justice at the level of theory" (Rorty 1989, xiv) — can be read in a more conventionally and innocuously liberal way. At bottom, Rorty's argument rests on a familiarly and quintessentially liberal series of claims about the kind of moral creatures we happen to be. We are individual beings with personal preferences, ambitions and tastes. Yet we are also beings with the capacity for reflecting on just social and political arrangements in abstraction from those very idiosyncratic projects and tastes. Thomas Nagel's important

5 Is it correct to understand loyalty as an inclination of the heart? Perhaps loyalty is better understood as something steadfast and dutiful. While there is certainly a use of the term "loyalty" that applies to steadfastness and duty (think for instance of the British/Canadian "loyalists" at the time of the American Revolutionary war), I am skeptical that that is what Rorty has in mind. After all, if "justice as larger loyalty" is meant to contrast with what Kant thinks we need from a theory of justice (viz., universal duties grounded in universal reason), then that reading is less likely.

6 It does not follow of course that religion is never a legitimate site for state coercion. To say that inner faith cannot be produced by compulsion, as Locke famously does, is not to say therefore that the outward acts of religious believers are for that very reason illicit targets of state intervention as well. William Galston (1991) observes that it was Thomas Jefferson who acutely zeroed in on precisely this distinction when he concluded that, whereas "the operations of the mind" are not appropriate objects of coercion, the "acts of the body" are. Cf. Jefferson 1975 . 
distinction between the "personal" and "impersonal" perspectives is in point here, as is John Rawls's discussion of "two kinds of moral powers" and the division of standpoints in each of us that accompanies it. The distinction drawn by Ronald Dworkin between "personal" and "external" preferences is also germane. The former has to do with one's "own enjoyment of some goods or opportunities," the latter with "the assignment of goods and opportunities to others." (Dworkin 1977, 234) I am suggesting that more or less the same idea lies at the heart of Rorty's view that private projects of self-creation need not be consolidated philosophically with the public, liberal project of reducing suffering and cruelty. Rorty's "liberal ironist" is committed to making her private life beautiful and her public life humane. She is quick to admit, however, that these disparate commitments may have little or nothing to do with each other. It is essential to all such liberal views-whether Locke's, Rawls's, Dworkin's or Rorty's - that human beings have the capacity to separate, even if only provisionally and temporarily, questions that arise about their own conception of a good life from questions that arise about just social and political arrangements. The possibility of such separation makes the "justice as larger loyalty" proposal an awkwardly framed one.

\section{Rorty's "Minimal" Liberalism and the Procedural Republic}

Yet even if loyalty was the sort of thing people could be compelled to have, it is easy to imagine Rorty thinking that such compulsion would still be a bad thing. For there are moments in Rorty's writing at which loyalty is made to seem, not merely extraneous to justice, but a possible impediment to it. One such moment occurs in a reply to Clifford Geertz's insistence on the need for "agents of love" and "connoisseurs of diversity". Rorty replies, roughly, that a society built around procedural justice needs agents who do not look too closely into what love and other inclinations of the heart might demand of us.

We do not really want doctors to differentiate between the values of the lives they are saving, any more than we want defense lawyers to worry too much about the innocence of their clients, or teachers to worry about which students will make the best use of the education they are offering.

7 See Nagel 1991 and Rawls 2001. T.M. Scanlon's distinction between "principles of justice" and "principles of individual conduct" is yet another example in the same neighborhood. (Scanlon 1998, 228). 
A society built around procedural justice needs agents who do not look too closely at such matters.

RORTY 1991A, 205

And, he continues,

The fact that lots of doctors, lawyers and teachers are unable to imagine themselves in the shoes of lots of their patients, clients and students does not show that anything is taking place in the dark. There is light enough for them to get their job done, and to do it right. The only sense in which something [takes] place in the dark is the sense in which all human relations untouched by love take place in the dark. This is an extended sense of 'in the dark' analogous to the extended sense of 'alone' in which we mortal millions live alone. When we gun down the psychopath, or send the war criminal to the gallows, we are, in this extended sense, acting in the dark. For if we had watched the war criminal grow up, had traveled the road he had traveled, we might have had difficulty reconciling the demands of love and justice. But it is well for society that in most cases our ignorance permits us to avoid this dilemma. Most of the time, justice has to be enough.

1991A, 205-6

The idea here is that justice should be blind and impartial. It is best stated in what Rorty calls a "banal moral vocabulary"(cf. Rorty 1991b, 196) and is best conceived of as swinging free of loyalty, love, and fellow feeling. The purpose of a just liberal state, Rorty has it, "is not to invent or create anything, but simply to make it as easy as possible for people to achieve their wildly different private ends without hurting each other...Our public dealings with our fellow citizens are not supposed to be Romantic or inventive; they are supposed to have the routine intelligibility of the marketplace or the courtroom."8 (Rorty 1991b, 196) As Alan Ryan puts a stronger version of the same point,

Justice is a political or institutional virtue more aptly practiced by people who do not have warm ties to one another... We do not want the judge to

8 I am admittedly unsure how to square Rorty's (Hobbesian) claim that the point of liberal institutions is to let citizens pursue their diverse ends without hurting each other with something else he says, viz., "a procedural republic instills virtuous habits in its citizens by arranging for them to experience what Hume called 'a progress of sentiments'” (Rorty 1998c, 121) But these are two ends that can and do easily come apart. 
allow natural feeling to swamp his desire to do justice to the plaintiff before him, but we do want intimate relationships to be sustained by natural feeling. A person who practiced only what justice demanded would be an odd fish and a cold one.

RYAN 1993, 4

Another way to express the idea common to Rorty and Ryan is to say that a just world is not by definition a perfect one, a world incapable of improvement. On the contrary, there are varieties of moral progress and regress about which the virtue of justice is silent. Conceiving of justice in this limited, liberal fashion has the obvious advantage of letting us ask whether a society is just without knowing what is in everyone's heart, without knowing to whom or to what each person feels loyal. It is true that a just but sentimentally cold world is inferior to one in which increasing numbers of human relationships are animated by love, loyalty and fellow feeling. But pointing this out is not to say something interesting about the virtue of justice. It only means, once again, that there are ways of praising or condemning the world about which the virtue of justice has nothing to contribute.

Restricting the ambit of justice in this familiar liberal fashion does not excuse individuals morally from the need to critically reflect on their emotional responses. Nor does it mean that larger loyalty cannot be encouraged and cultivated over time, or even that such cultivation would be ruled out on paternalist grounds. Rorty himself has been a champion of the view that novels and poetry can be acute sources of moral progress by aiding in the process of popularizing alternative descriptions, a process which is the driving force both for private projects of self-creation and a more humane (less cruel) public culture. As he explains, "Something traditionally regarded as a moral abomination can become an object of general satisfaction, or conversely, as a result of the increased popularity of an alternative description of what is happening. Such popularity extends logical space by making descriptions of situations that used to seem crazy seem sane." (Rorty 1998a, 204) While Rorty sometimes goes too far in denying that rational argument can also play a role here, ${ }^{9}$ he does think the difference between "crazy" and "sane" descriptions turns mainly

9 Consider: "The answer to Nozick is not Aristotle or Augustine or Kant, but, for example, the writings of William Julius Wilson, and the autobiographies of kids who grew up in urban ghettos." We do not respond to the libertarian by appeal to rational first principles, Rorty has it, but by telling "sob stories about what happens to the poor in nonredistributivist societies" (Rorty 1998c, 121). But surely one can answer Nozick with a few arguments too. There is no reason to think that the choice between arguments or sob stories is an exclusive one. 
on feeling and "soppy sentimentality". "Moral education," he says, "is sentimental or nothing." (Rorty 1998c, 121) On this view moral progress is achieved primarily through the manipulation of sentiments. It "gets people of different kinds sufficiently well acquainted with one another that they are less tempted to think of those different from themselves as only quasi-human. The goal of this sort of manipulation of sentiment is to expand the reference of the terms 'our kind of people' and 'people like us'”. (Rorty 1998a, 176)

One can believe that the cultivation of larger loyalty is a laudable aimRorty clearly believes that it is - but it need not follow that smaller loyalties are less just and larger ones more just. To belabor the point once more, not every laudable aim is properly conceived as a requirement of justice. There are many good and bad ideas that justice neither requires nor rules out. Justice, in short and to sum up, is only one of the evaluations we make of the world. It is by no means the only consideration that bears on the questions, "What ought to be done"? and "What sort of future is worth working toward?"

\section{Conclusion}

It is easy to imagine Rorty rejoining that in putting forward the "justice as larger loyalty" idea, he was using the term "justice" in a slightly different sense. This is the sense in which "justice" is used as vaguely coextensive with a utopian future, as shorthand for "the best society we can think of". Is this not a perfectly sensible and correct way to use the term? And if so, isn't it arbitrary to restrict the ambit of justice as I have been urging? As David Miller smartly points out,

It looks arbitrary to attach the label 'justice' to one segment of morality rather than another...If one takes the ordinary use of language as a touchstone...[people will say] that it is unjust for rights to be violated, but they will also say - depending on the circumstances but with equal confidence - that it is unjust if people do not get what they deserve, that it is unjust if people are deprived of what they genuinely need, that it is unjust when people are treated unequally, and so on. What authority, then, do restrictive claims [about justice]... actually have?"

MILLER 2013, 57

To be clear, I am not charging that Rorty's "justice as larger loyalty" idea is a category mistake. ${ }^{10}$ Nor have I argued that conceiving of justice as larger

10 Here it is worth recalling an important passage from Rawls's $A$ Theory of Justice: "Many different kinds of things are said to be just and unjust: not only laws, institutions, and 
loyalty violates the ordinary linguistic use of the term "justice". My argument is simply that this proposal sits uncomfortably with important strands of Rorty's own political thought. On a properly liberal, Rortyan view, it would be better to think of "larger loyalty" not as an account of justice at all, but rather, putting it in the language of Marx and Engels, as a description of its transcendence. So long as loyalty is limited, we will need justice to ensure that no one gets unjustifiably harmed or excluded. A world with sufficiently large loyalty is not a perfectly just world but rather one in which the need for justice is no longer there. Otherwise put, limited loyalty should be thought of as one of the circumstances of justice, not an impediment to its realization. In a moving passage, Rorty associates such a justice-transcending world with his sense of the holy.

My sense of the holy, insofar as I have one, is bound up with the hope that someday, any millennium now, my remote descendants will live in a global civilization in which love is pretty much the only law. In such a society, communication would be domination-free, class and caste would be unknown, hierarchy would be a matter of temporary pragmatic convenience, and power would be entirely at the disposal of the free agreement of a literate and well educated electorate.

RORTY 2005, 40

That Rorty here associates such hopes with his sense of the holy rather than with justice per se adds substance to the argument I have been making. It suggests that we can think of justice with the concrete, routinely intelligible, "banal moral vocabulary" Rorty encourages us to employ, while simultaneously letting "the imagination play upon the possibilities of a utopian future" (Rorty 1999, 239) without worrying that these two ambitions are at odds with each other. There is nothing contradictory in being "concrete and banal when talking real politics [and justice]" on the one hand, and being "abstract, hyperbolic, transgressive, and playful...when we turn, in a mood of relaxation, to cultural politics [and as yet unrealized utopian hopes]" on the other. (Rorty 1998a, 231-2) The assurance that these two kinds of enterprises need not be

social systems, but also particular actions of many kinds, including decisions, judgments, and imputations. We also call the attitudes and dispositions of persons, and persons themselves, just and unjust. Our topic, however, is that of social justice. For us the primary subject of justice is the basic structure of society, or more exactly, the way in which the major social institutions distribute fundamental rights and duties and determine the division of advantages from social cooperation." (Rawls 1971, 7). 
consolidated at the level of theory is perhaps Rorty's most enduring contribution to political philosophy and the topic of justice.

My argument in this essay can be summed up with the quintessentially Rortyan thought that a tool designed for one purpose may be poorly suited (or counter-productive, even) for another purpose. To the extent that Rorty's "justice as larger loyalty" proposal is understood strictly as yet another weapon with which to attack Kant, I have conceded that the proposal is an admirable one. But part of my argument has been that attacking Kant in this way may come at too high a cost. For conceiving of justice as larger loyalty comes dangerously close to conflating the banal clarity and unambiguous intelligibility required by justice in the real world with the aestheticized, imaginative novelty needed for dreaming up marvelously new and better utopias. It would be a fitting tribute to Rorty's legacy, I think, if we continued to think of ways emphasizing the feeling, sentimental dimension of our moral lives against the prevailing Kantian Rationalism while making sure that, in the process, we do not run together real politics and cultural politics.

\section{Acknowledgements}

This paper began as a contribution to a panel on "Pragmatism and Justice" held at the annual meeting of the Society for the Advancement of American Philosophy in 2013. I am grateful to my fellow panelists, Susan Dieleman and Christopher Voparil, for valuable comments and discussion. Thanks also to Colin Koopman, Kai Nielsen, Gregory Fernando Pappas, Katharine Schweitzer and Chris Williams who read earlier drafts and offered perceptive comments.

\section{References}

Allen, Barry. (2004) Knowledge and Civilization. Boulder, co: Westview.

- (2008) "A More Laudable Truthfulness". Common Knowledge 14 (2), 193-200.

Anderson, Elizabeth. (2010) "The Fundamental Disagreement between Luck Egalitarians and Relational Egalitarians." In Justice and Equality, edited by Colin MacLeod. Calgary: University of Calgary Press.

Dewey, John, and James Tufts. (1926) Ethics. New York: Henry Holt and Co.

Dworkin, Ronald. (1977) Taking Rights Seriously. London: Duckworth.

Galston, William. (1991) Liberal Purposes. Cambridge: Cambridge University Press.

Jefferson, Thomas. (1975) The Portable Thomas Jefferson. Edited by M. D. Peterson.

Harmondsworth, UK.: Penguin. 
Joyce, James. (2011) Portrait of the Artist as a Young Man. Blacksburg, VA.: Wilder. Miller, David. (2013) Justice for Earthlings. Cambridge: Cambridge University Press. Nagel, Thomas. (1991) Equality and Partiality. Oxford: Oxford University Press. Rawls, John. (1971) A Theory of Justice. Cambridge: Harvard University Press.

- (2001) Justice as Fairness: A Restatement. Edited by E. Kelly. Cambridge: Harvard University Press.

Rorty, Richard. (1979) Philosophy and the Mirror of Nature. Princeton: Princeton University Press.

- (1989) Contingency, Irony, and Solidarity. Cambridge: Cambridge University Press.

- (1991a) Objectivity, Relativism, and Truth. Cambridge: Cambridge University Press.

- (1991b) Essays on Heidegger and Others. Cambridge: Cambridge University Press.

- (1998a) Truth and Progress. Cambridge: Cambridge University Press.

—. (1998b) Achieving Our Country. Cambridge: Harvard University Press.

—. (1998c) “A Defense of Minimalist Liberalism”. In Debating Democracy's Discontent:

Essays on American Politics, Law, and Public Philosophy, edited by A. L. Allen and

M. C. Regan. Oxford: Oxford University Press.

- (1999) Philosophy and Social Hope. London: Penguin.

- (2001) "Justice as Larger Loyalty". In Richard Rorty: Critical Dialogues, edited by M. Festenstein and S. Thompson. Cambridge: Polity.

- (2002) Against Bosses, Against Oligarchies. Chicago: Prickly Paradigm Press.

- (2005) The Future of Religion. (With Gianni Vattimo) New York: Columbia University Press.

- (2007) Philosophy as Cultural Politics. Cambridge: Cambridge University Press.

- (2010a) "Reply to Jacquelyn Ann K. Kegley". In The Philosophy of Richard Rorty:

The Library of Living Philosophers, vol. XXXII. Chicago: Open Court.

- (2010b) "Intellectual Autobiography". In The Philosophy of Richard Rorty: The Library of Living Philosophers, vol. XXxII. Chicago: Open Court.

Royce, Josiah. (2005) The Basic Writings of Josiah Royce, Volume 2: Logic, Loyalty, and Community, edited by J.J. McDermott. New York: Fordham University Press. Ryan, Alan. (1993) Justice. Oxford: Clarendon.

Scanlon, T.M. (1998) What We Owe to Each Other. Cambridge: Harvard University Press. Talisse, Robert. (2014) "Deweyan Democracy and the Absence of Justice." In Graham Hubbs and Douglas Lind (eds.) Pragmatism, Law, and Language. New York: Routledge. 